\title{
Refugees from Suriname
}

\author{
by Betty Sedoc-Dahlberg
}

\begin{abstract}
The Inter-American Commission on Human Rights in Washington published a brief report on the situation of human rights in Suriname in October 1983 following a visit of a special commission in June of that year. The report questions the government's expressed intention to allow for the expression of popular will or to permit freedom in the media. The Commission concluded that serious violations of important human rights occurred.

The International Commission of Jurists in Geneva also published a report entitled "Human Rights in Suriname" which concluded that "the chain of events since 1980 demonstrates an escalation in the military authority's disregard for the rule of law, which is set aside whenever they consider it necessary for the consolidation of their position." This characteristic report provides background information to the creation of refugees from Suriname in the Netherlands.
\end{abstract}

\section{Introduction}

The lack of political responsibility by the weak Surinamese governments is demonstrated through the absence of interest in the migration of $25 \%$ of the population to the Netherlands. Increasing social unrest gave rise to an uninterested and uncaring attitude towards the migration of professionals, technicians, and skilled workers since the fifties: in the sixties and seventies, the so-called crisis strata and socially explosive elements of the society followed. Moreover, after the 1980 military take-over by non-commissioned officers, the power elites developed strategies to encourage migration of so-called "destabilizing" countrymen. A massacre in December 1982 by the nearly three-year old leftist junta led to the involuntary migration to the Netherlands of more than one thousand persons of several ethnic groups.

These migrants consisted mainly of politicians (of the left and right among whom were some disgraced ex-members of the military government), academics, students, teachers, administrators, trade union leaders, entrepreneurs and journalists. Many of these civilians are spokesmen, representatives or associates of political parties, religious organizations, labour unions and other professional organizations that in November 1982 urged general elections and the return of the army to their barracks. They form a category apart in Holland and are loosely organized in several bodies (which connect them with their homeland) among which the National Liberation Council is the most prominent. In the past 14 months of their existence, many Surinamese refugees have been engaged in a struggle for survival. Those who have found jobs and housing accommodation appear to lose their direct interest and involvement in the liberation movement.

\section{Surinamese in the Netherlands}

The former colonial powers have often served as places of escape in times of uncertainty and persecution in newly independent nations. With reference to Suriname, some specific characteristics have to be taken into account which explain the continuation of an exclusive Dutch orientation. Two important characteristics are the Dutch language and educational system, which isolate Suriname from the Western Hemisphere. Within the Kingdom of the Netherlands, the Dutch Antilles, which are located in the Caribbean Sea, are the exception. Thus, a concentration of Surinamese on some of these islands is not surprising.

However, even before independence in 1975 , it is estimated that $20 \%$ of the Surinamese population was living in Holland. Many Surinamese migrant families in Holland have served for two generations as reception centers for thousands of Surinamese facing problems in their home country. Furthermore, the changing political elites and power aggregates have often caused many migrants to remain temporarily in Holland.

Significant migration to Holland began in the 20th Century and became visible after the 1940's, when more members of well-to-do Creole and Jewish families left for Holland, followed in the 1960's and 1970's by members of other ethnic groups and representatives of other socioeconomic strata.

Since the 1970's, the Dutch government has tried to establish migration policies to stop this influx of Surinamese and to promote return migration. It was believed that Surinamese migration to the Netherlands was typified by a so-called "follow-up" migration; that is, the migration process itself is facilitated by social networks of families and communities that extend across national borders in the Netherlands. This implies that once a key member of the family has settled abroad, the other members will eventually follow. The Surinamese government believed that return migration was connected to social welfare projects, with special attention to the elderly. Thus, they believed that the implementation of return-migration policies for key family members, such as parents, would also stimulate other persons in the family to migrate back to Suriname. The validity of this theory has never been proven and living conditions were not significantly improved after independence.

It is also possible that migration was seen by certain politicians as a mecha-

Continued on p. 6 
Suriname Refugees

Continued from p. 5

nism to rid themselves of "trouble makers" in the country. This implies that a negative attitude existed toward return migration policies. The increasing economic depression in the 1960's and the rise of racial conflicts between Surinamese and Dutch in Holland are, in our opinion, two crucial factors that caused the former colonial power to promote strong return migration policies. The systematic delay in the operationalization of these policies by the Surinamese government is probably an important and contributing factor that negatively influenced the Suriname-Dutch relationship before 1980 .

During the independence negotiations in 1974-75, it was agreed that people would be able to travel freely between Suriname and Holland until November 1980. Before that time, those who returned to Suriname with a Dutch passport would automatically become Surinamese after a two-year stay in their country. A policy to prevent further migration to Holland was implemented in 1980.
Beginning in November 1980, those Surinamese who stayed longer in Holland (as for a vacation period), were required to have a working permit with adequate housing accommodation as a precondition. Moreover, a visa was required to enter the Netherlands. However, many Surinamese continued to visit their relatives in Holland during the holidays. A special agreement on the unifying-of-dependents again created many disputes because of the complicated family social networks in Suriname. Holland indeed was a second home for many Surinamese and in many cases, Surinamese became 'shuttle migrants' who did not belong to either country. This is very true for professionals and academics who were almost all trained in the Netherlands.

Against this background, one can understand how after the December 1982 massacre, Holland was the most important escape route for Surinamese. At that time, the Dutch embassy softened their entrance blockade for humanitarian reasons and even offered facilities for dependents of those killed by the

junta.

\section{Dutch refugee policies}

Since Holland is a signatory to the UN convention on Refugees, the Dutch government recognizes refugee status within its migration laws. The relationship between the violation of human rights and involuntary migration is recognized. The receiving country aims at guaranteeing the refugees ('grootst mogelijke') fundamental rights and freedoms (Treaty 1951). With regard to Surinamese refugees, it is important to note the statement delivered by the deputy secretary of the Ministry of Justice: "Because of special linkages with Suriname, the Ministry of Justice deviates from the rules in not demanding refugees to present a request for asylum in the first receiving country. For that reason, Surinamese who entered Holland via Miami or French Guyana were not refused." Furthermore, "Surinamese who were in trouble because of the brutal events in December 1982 can obtain a visa within 24 hours and leave directly thereafter."

However, Surinamese who entered Holland after the massacre are considered foreigners, despite the specific relation that exists between The Netherlands and Suriname. Once in Holland, a maximum three month visa can be renewed for another three months. This implies that those who did not ask for a permit to stay earlier, or those who could not or did not wish to take such a decision with regard to their departure to Suriname, can afford to legally stay three extra months. If, however, after two periods of stay on a visa in Holland, the person decides not to leave for Suriname, a permit to stay and a request for asylum is required. Regarding decisions to grant asylum, "fear of persecution" or "threatening of security" (bedreiging van de veiligheld) are considered to be crucial criteria. The general policies are not based on a continuation of stay for economic motives. There are no special receiving and guiding facilities (opvang en begeleidingsfaciliteiten) for the refugees from Suriname. In general the following procedures are applied:

- A stay in The Netherlands on a visa offers no facilities, and specifically no

6 


\section{NON-DUTCH MIGRATION BETWEEN THE NETHERLANDS AND SURINAME}

\begin{tabular}{rrrr}
\hline YEAR & IMMIGRATION & EMIGRATION & $\begin{array}{c}\text { DIFEERENCE } \\
\text { I-E }\end{array}$ \\
\hline 1977 & 2,662 & 604 & 2,058 \\
1978 & 5,211 & 523 & 4,688 \\
1979 & 16,060 & 737 & 15,323 \\
1980 & 16,989 & 978 & 16,011 \\
1981 & 3,152 & 1,246 & 1,906 \\
1982 & 2,015 & 1,033 & 982
\end{tabular}

On January 1, 1981, 25,000 persons were in the Netherlands coming from Suriname (not-Dutch). The numbers of persons, coming from Suriname with a Dutch nationality is estimated at 115,000 .

Source: Central Bureau for Statistics (CBS), Maandstatistiek van de Bevolking.

benefits are available.

- Surinamese, who obtain a permit to stay or those who are allowed to wait for such a decision in Holland, can receive benefits based on a document known as "circulaire inzake bijstand aan vreemdelingen."

- Surinamese with refugee status (A- or $\mathrm{B}$-status) are eligible for benefits and are offered housing facilities.

Those who obtained the A-status can even receive a government scholarship, known as "rijksstudietoelage". Surinamese involuntary migrants, who entered Holland after the massacre of December 1982, can be placed in the following categories according to Dutch refugee policies:

a. Refugees with a formal status (A-status) Facilities: housing, benefits, study grant. (rijks-studietoelage) b. Refugees with a formal status (B-status) of: Facilities: housing, benefits (bijstand), financial aid.

c. Refugees on humanitarian criteria. No formal refugee status, facilities limited to financial aid.

d. Refugees without any specific status. Formally tourists on a visa with a permit to stay a maximum of 6 months.

e. Surinamese refugees of Dutch nationality. All facilities normally offered to Dutch. f. Military refugees. Those who have a permit to stay can join the Dutch army after naturalization.

g. Surinamese who returned to their country with the aid of the Dutch government (return migrants) and may become unemployed because of the postponement of Dutch development aid. No special policies. Treated as normal cases.

h. Surinamese without manifest escape motives (duidelijke vluchtmotieven). (Tourists on a visa).

\section{Involuntary Migration: a response on violence and oppression}

Between December 1982 and March 26, 1983, 4107 Surinamese applied for a visa at the Dutch Embassy in Suriname; 1444 visas were compiled. Of the 1444 persons with a visa, 125 requested a permit to stay in Holland and 45 persons obtained this permit. (Sept. 1983). It is important to note that $65 \%$ of those who tried to escape to Holland after the massacre were unable to do so because the Dutch embassy refused to deliver them a visa. Moreover, only $45(0.03 \%)$ who successfully obtained a visa received a permit to stay in Holland. (Sept. 7, 1983). It is true that 125 persons requested a permit to stay, but the increased fear and uncertainty in Suriname does not indicate that the majori- ty of people who left the country in December preferred to return home. It is probable that most of these people had no choice: they could either leave the Netherlands or go into hiding.

Regarding this last category, the Dutch statement, "Surinamese who left their country because of reasons of security, can stay in Holland as long as this is required..." appears to be false. The assertion: "Also Surinamese who are illegal in Holland and who fear persecution if they are sent back, have the possibility to ask for a permit...", may also be misleading. Since the maximum legal stay in Holland was 6 months in September 1983, we must conclude that almost all the Surinamese (92\%), except the 125 who requested a permit, left for Suriname or are illegally residing in the Netherlands. It appears that Dutch officials, civil servants (particularly at local levels), are badly informed and/or are not stimulated (by their attitude towards Surinamese refugees) to accommodate refugees. On the other hand, many Surinamese are not familiar with these Dutch procedures and apply for refugee status in an inappropriate manner. Contemporary razzias on "illegal Surinamese" and their deportation make the formal statements by the Dutch government concerning refugees debatable.

Although the government appears to be concerned with the plight of the refugees, in reality, discriminating policies were carried out except against the most privileged and educated Surinamese (particularly those educated in Holland) and the top Surinamese professionals. In short, the Dutch government's statements concerning refugees do not recognize the denial of permits to most Surinamese who have tried to migrate to Holland.

\section{Profile of the Surinamese Refugees in Holland: An Initial Sketch}

Who are the ones that are referred to as Surinamese refugees? Do they fit the 1980 UN definition of refugees?

An attempt will be made to outline the characteristics that typify this Surinamese migrant category. This provides more insight into several identified and unidentified problem areas from a Continued on $p .8$ 


\section{Suriname Refugees}

\section{Continued from p. 7}

humanitarian as well as a policy making perspective. From the available in complete information, we consider relevant:

- categories involved; age, ethnic background, occupation (military/ civic) social-economic position;

- status in Holland; legal, employment, accommodation.

Approximately 400 persons have registered for a political asylum request. A few of them successfully obtained this status. Five categories of refugees who received their formal refugee status can be distinguished:

1) Professionals (academics, journalists, businessmen, politicians etc.), who through their connections can find their way in Holland without the help of the Foundation for Surinames Refugees. They belong to the more privileged category of refugees.

2) Spokesmen and leaders, usually affiliated with labour unions and other interest groups. They have been organized in the Association for the Restoration of Democracy and accused by the military.

3) Commissioned officers of the Suriname army. Together with colleagues who earlier (between 1980 and 1982) left Suriname. This category is represented by the top professional military of the country.

4) Soldiers who escaped from the army. Most of them crossed the east border river and entered into French Guyana. They continued their trip from there to Holland.

5) Students who were involved in demonstrations against the military junta. Most of them are university students.

Of these five categories, members of the first three were the most successful. Soldiers who could show their military call-up received a temporary staying permit. Many students argued that "the re-organization of the University to a People's University within a communistic framework" (as was announced) is not acceptable to them. Most of these students are not registered. It is well known that the Suriname government only permits the transfer of money to students who can prove that they want to study a field not provided by the

\title{
Suriname: Some
}

\section{February MILITARY TAKE- OVER}

March

The First Military Government.

May

Government Declaration on Labour Day (promising):

- elections (general) within two years,

- a law on political parties,

- a new Constitution,

- maintaining of human rights.

August

Coup attempt by Marxist-Leninists.

Participants arrested.

Deposition of President (Constitutional).

Adjournment of the Constitution.

Abolishment of the House of Parliament.

1980 August JURIDICAL TAKE-OVER

Issuance of decree: regulating power of Policy Center.

1981 March

Release of the Communists jailed for the coup attempt in August 1980.

December

Proclamation of the Revolutionary Front.

1982 February

Deposition of the P.M.

\author{
March \\ A two-day take-over by Rambocus \\ and Hawker: promising \\ - general elections, \\ - military back to their barracks. \\ April \\ Installation of the Second Military \\ Government. \\ June \\ The foundation of a People's Militia \\ consisting of many members of the \\ $\mathrm{RVP}^{*}$ later also PALU ${ }^{*}$.) \\ First trained militaries from Cuba \\ returned to Suriname. \\ October/November \\ Increasing protest of spokesmen and \\ leaders of interest groups against the op- \\ pression. \\ University staff, administrive and \\ technical personnel and students against \\ the junta. \\ Open conflict with churches. \\ federation: het A.V.V.S. de Moeder- \\ bond. \\ Open conflict with churches \\ Urging an association for democracy \\ and return of the military to their bar- \\ racks. \\ December \\ Massacre; 15 spokesmen of the people \\ tortured and killed by the junta.
}

government of Suriname. Like other youngsters, they are unaware of the procedures and the assistance they can receive to legalize their stay in Holland. Since they also fear deportation to Suriname, many of them prefer to go into hiding. With regard to the ethnic background of the refugees, there are strong indications that the majority are Creoles and Hindustani.

Most of the refugees left Suriname without their dependents. Apart from the youngsters, a large number of refugees now have to deal with families that have split up. Difficulties with the transfer of money from Suriname to Holland make the often unemployed migrants more vulnerable in the Dutch society. The migrants whose depen- dents migrated to Holland often face housing problems.

\section{Future Perspectives}

We now know that approximately 1444 Surinamese left their country involuntary after the massacre of December 1982. Most of these Surinamese entered The Netherlands as tourists; some civil servants were able to obtain a formal permit to leave. We have also discovered that a few of them were successful in finding jobs in Holland but the majority remain unemployed. This implies that in most cases, aid from relatives as well as from Surinamese and Dutch friends is needed in order to survive while exploring job opportunities. Finally, an organizational framework exists which unites refugees who wish to 


\section{Crucial Events in the 80's}

University of Suriname closed down by the junta.

Abolishment of the free press.

Prohibition for newspapers and weeklies, and for broadcasting corporations.

\section{January}

Anti-Intervention Committees (AIC's) in industries and business to identify, locate and fight mercernaries.

Founding of Committees to demonstrate solidarity with the 'revolution' in parastatale institutions and ministries. (with AIC's function).

March

Founding of the Youth Militia (Organization to militarize youngsters between $12-16$ years).

April

Installation of the Third Military Government chaired by a member of PALU.

\section{May}

Announcements at Labour Day of the extension of the council-network on several levels of policy-and decisionmaking.

August

Announcement of a one-party system. To be proclaimed at November 25, 1983. Support of all interest groups and political parties expected.

September/October

Continuation of replacements of the I and II echelon key positions by RVPers. Decreasing PALU influence.

Announcement of highly qualified ideological training by RVPers (for local and regional level).

*RVP (Revolutionary People's Party) and PALU (Party of Poor Peasants and Farmers): Both competing MarxistLeninist parties.

Note: Events related to foreign powers' influence on local circumstances are left out. As such, the suspension of the Dutch and US aid after the massacre (December 1982); the Cuban involvement in the countries domestic affairs (since March 1981); the Brazilian warning of communism and Cubans in Suriname (April 1983); the expulsion of the Cuban ambassador and advisors and suspension of agreements between the two countries (October 1983) are not included in this scheme. The influence of these events on decisions made by the junta is, however, not neglected. return to Suriname.

What will be the fate of the refugees? The answer to this question is closely related to the question: What will be the future of their country? We do not try to predict future events since the situation is quite complex and there is a lack of information. But we can identify factors relevant for monitoring purposes. In this respect, the attitude of the Dutch government, for economical and political reasons, is considered to be crucial because of its relationship with the junta as well as with refugee organizations that aim for the liberation of the country.

New developments in the SurinameDutch relationship became evident in December 1982 after the massacre when the Dutch stopped development aid because of human rights violations. Furthermore, the anti-Dutch propaganda perpetrated by international organizations, particularly during the New Delhi Non-Alignment Movement meeting, worsened the relationship. However, since the establishment of the National Liberation Council in January 1983, the Dutch have resisted having a Surinamese government in exile in their country, mainly because of their formal relations with the junta. As a consequence, the movement was curtailed and lost its political impact both in and outside of Holland.

It is possible that the findings of a secret 1981 Defense report discovered by two Dutch journalists concerning the involvement of members of the Dutch
Military Mission in Suriname (published in Vrij Nederland) will influence the attitude of the Dutch. It is stated that the Dutch government was not informed of the existence of this document. It is now evident that the advice given by investigator Major Koenders (i.e. to do nothing with the findings because of their negative effect on the SurinameDutch relationship), is no longer valid. This implies that the Dutch are free to begin a military and criminal investigation. At this time, there are a sufficient number of Dutch and Suriname military professionals available in Holland. Moreover, a number of them confirmed publicly in Dutch television interviews that proposals were made by the Dutch colonel of the Military Mission of the Embassy of the Netherlands to eliminate the top army officers to overthrow the government. Furthermore, from Vrij Nederland stated that the involvement of the Dutch officers in the military takeover allowed the Suriname colonel to blackmail the Dutch government. Thus, "Colonel Bouterse needs only to threaten to make announcements of the Dutch involvement in the coup to have the Dutch cover up the aberrations which also occurred before December 1982."

The attitude of the refugees themselves as well as their frame of reference are considered key variables. How long will their team spirit last? And how far is continuation influenced and even frustrated by disappointments because of amateurism, reflecting a lack of knowhow? Will their morale decrease because of set-backs of successful infiltration of unreliable elements?

In conclusion, more insight is needed on these key factors:

a. The attitude of the Dutch: reflecting the societal embedding of refugees which informs us about the support, or the discouragement of their activities.

b. Manpower: in terms of available know-how and support of the Surinamese community in Holland.

c. The attitude and frame of reference of the refugees, which is so strongly tied to their conceptualization of future perspectives.

d. The means: this key variable is not really explored because of a lack of insight into these matters as well as the lack of any information.

Continued on p. 10 


\section{Suriname Refugees}

Continued from $p .9$

The thoughts of some leaders in exile are clear: Suriname might become a satellite of the Second World." However, liberation of the country and restoration of democracy should never imply the reestablishment of the pre-1980 status as a satellite of the First World.

\section{Closing Remarks}

From the findings of this exploratory study we have learned that the Surinamese political refugees form a heterogeneous entity. With regard to their future, significant differences in the ideological frame of reference and the attitude toward violence appear to be decisive.

With regard to disputes on the application of political refugee status, this Suriname migrant category meets the requirements as defined in the UN in 1980 since "well founded fears of persecution because of membership in particular social groups or political opinion" is evident. As such, it is in the refugees' interest to explore international options for settlement and to work out contacts with other similar entities.

As a proponent for democracy and human rights, might one expect that the Dutch government (especially after the findings of the 1981 secret CID report) would reject the junta, and change its policy with regard to Suriname and its refugees as well as make contributions to recover the civil and political rights the Surinamese have lost. There would be solid support for Surinamese refugees and their organizations. Domestic policies as well as cooperation with international organizations should reflect this attitude.

In general, one can say that in societies such as Suriname, where a certain degree of militarization has taken place and where decision making and the political machinery are controlled by a junta or heavily influenced by armed forces, a distinction between authoritarian and totalitarian governments, in terms of human rights and freedoms, is hardly relevant. In such nations, involuntary migration is considered inherent to the transitional process leading to such governments.

Betty Sedoc-Dahlberg is a Surinamese and is the ex-rector of the University of Suriname. She is presently teaching policy and planning for development in the Caribbean. A Fulbright scholar, she is currently a Visiting Professor at the Center of Latin American Studies, University of Florida.

Telephone: (904) 393-0375 (o)

(904) 373-1832 (h)

Address: Center of Latin American Studies Grinter Hall, Room 382

University of Florida

Gainesville, Florida

U.S.A. 32611

\section{Extracts from the 34th Session of the Executive Commissioner's Programme of the High Committee}

"Draft Principles on the Prohibition of Military and Armed Attacks on Refugee Camps and Settlements"

- Camps and settlements accommodating refugees shall not be the object of military or armed attacks.

- Military attacks on refugee camps and settlements are in grave violation of existing and fundamental principles of international humanitarian law. They can never be justified under any circumstances and must consequently always be condemned.

- Refugee camps and settlements shall be used exclusively for civilian and humanitarian purposes.

- Military attacks on refugee camps or settlements should be expressly condemned by the international community and all possible action should be taken in the relevant bodies of the United Nations and other organisations to prevent such attacks or their recurrence.

- States in whose territory refugee camps and settlements are located, shall do all within their capacity to ensure that the exclusively civilian and humanitarian character of such camps and settlements is maintained and that they are protected against military attacks.

- Refugees in camps or settlements have duties deriving from the refuge and protection granted or afforded to them by the country of refuge or the country of asylum. In particular, they shall conform to the laws and regulations of the State of refuge or of asylum, including lawful measures taken for the maintenance of public order. Moreover, they shall refrain from any activity likely to endanger the exclusively civilian and humanitarian character of the camp or settlement.

\section{Brief Notes: The Standing Conference of Canadian Organizations Concerned for Refugees}

\section{Scarborough, Ontario \\ December 9-11}

1. There was a large attendance, though not equivalent to the heights of the Indochinese refugee movement.

2. There was much broader representation. In addition to the customary church, ethnic, human rights, immigrant aid societies, etc., there were representatives of Tamils from Sri Lanka, Assyrians from the Middle East, Bangladeshis, Ethiopians, Salvadoreans, etc.

3. The Honourable John Roberts, the Minister of Employment and Immigration, though invited, was not expected to come. He found time to attend the wine and cheese reception, however, and indicated in his brief speech that, after concentrating on employment policy in his first three or four months in office, he would now be turning his attention to immigration and refugee issues.

4. Dan Heap, MP for Spadina riding in Toronto and the NDP critic on immigration issues, was in attendance.

5. Raf Girard stated, "The visa requirement is a response to the number of refugee claimants and not the number of illegitimate claims." This statement seems to run counter to the Amnesty International policy that visa requirements should never be imposed on a refugee-producing country where there is no significant abuse.

6. Seventy-five percent of the Guatemalan claims in Canada are accepted.

7. Michael Schelew claimed that there is a practice (contrary to policy according to Raf Girard) of filling quotas for specific areas even when individuals in that area are not in danger.

8. In general, there was a sense of cooperation rather than antagonism between the NGOs and the government, and between the NGOs and the UNHCR in spite of differences on the refugee claim procedures. 